\title{
FOOD TOURISM AND THE USE OF AUTHENTICITY IN THAILAND
}

\author{
THANYA LUNCHAPRASITH* AND DONALD MACLEOD† \\ *International College, Silparkorn University, Bangkok, Thailand \\ $\dagger$ University of Glasgow, Crichton Campus, Dumfries, Scotland
}

\begin{abstract}
This article explores the concept of authenticity as it relates to its use by hosts at tourist destinations, the relationship between food and tourism, especially food produced and sold by market traders, and the various uses of authenticity by traders and tourists. It specifically aims to further our understanding of the use of authenticity in Thailand by stakeholders in a synergistic process, thereby filling a gap in research. Mixed research methods were used (interviews, questionnaires, and observation of the markets) with fieldwork totaling 6 months in Central Thailand. Eight different markets were chosen providing qualitative material leading to a sample of emic material on attitudes and approaches to authenticity, its construction, and utilization. It was found that authenticity, as it relates to traditional food markets, has been constructed by stakeholders. Authenticity may differ through the products, according to the personal experiences and motivations of the agents involved. Additionally, the tourists' experiences and expectations impact on the final product in an evolving process. It is recommended that traditional food may be further promoted in traditional markets by stimulating visitors' engagement in food culture. The article argues that authenticity, in its sociocultural constructivist context, is a relativistic phenomenon, which may be seen as existing in a continuum where there are degrees of authenticity.
\end{abstract}

\section{Key words: Food; Authenticity; Thailand; Traditional market; Stakeholders}

Introduction

Thailand has a population of 65 million (Thailandometers, 2016) and the number of international tourists in 2015 was 29.9 million, rising from 24.8 million in 2014 (National Statistics Office, 2016). Receipts from international tourists were US\$63.2 million in 2015 (World Tourism Organization, 2015). In 2015 there were 138.8 million domestic tourists (Thansettakij, 2016). Visitor numbers for the traditional food markets in Thailand (the focus of this article) are harder to come by as there are no official statistics; however, according to the market officials questioned in this study, there are between 3,000 and 7,000 visitors each day at individual markets, depending on various factors including the day of the week, the different markets, and the season. It is clear that tourism is 
a very important part of the economy for Thailand, and food tourism is growing in popularity, but has not reached its potential. This article proposes that studying authenticity is important in order to comprehend the potential of food to be promoted as a tourism product in Thailand.

Food tourism in Thailand is explored through employing the concept of authenticity and examining how tradition and modernity are negotiated throughout the process of creation, promotion, and consumption of food experiences. Consequently, those who are involved in the process of creation, promotion, and consumption are taken into account: market management officers, food vendors, and visitors.

The "Traditional" period (which defines the "traditional markets") is recognized in this article as the period preceding the "Modern" period. It was when agriculture dominated the way of life in Thailand, which began to decline in the 1960s (see Nartsupa, 1991; Reynolds, 2002). Traditional markets and nostalgia-themed markets are now popular attractions in Thailand. Traditional and local ways of life are converted into tourism experiences. Although the earliest touristic traditional markets (e.g., Damnoen Saduak Floating Market, which was established in 1960s) were developed to cater for foreign visitors eager to learn about Thai culture, later traditional markets are primarily made to target nostalgia-motivated domestic visitors (Yodsurang, Hiromi, \&Yasufumi, 2016) and this research article has its focus on domestic tourists.

According to the Tourism Authority of Thailand (TAT 2009), traditional markets can be entirely settled on the ground, but the more popular form of traditional market is located entirely or partially on the water (so-called floating market), reflecting the significant role of waterways as trade venues in the past. The success of the transformation of old rundown trade communities into tourist spots in the central region of Thailand in the early 21 st century has triggered the proliferation of traditional markets across the country. Many traditional markets serve not only as cultural attractions but are also known for gastronomy (Sakdiyakorn \& Sivarak, 2015; Siri-umpai, 2012; Wattanacharoensil \& Schuckert, 2014).

The traditional market is a cluster of old-fashioned food outlets from the local region (Pongajarn, van der Duim, \& Peters, 2016; Suntikul, 2013). Despite the potential of traditional gastronomy to provide a unique experience to tourists (Sakdiyakorn \& Sivarak, 2015), the role of gastronomic experiences remains underexplored compared to the large number of academic articles discussing traditional markets in terms of cultural landscapes, as well as community-based tourism (e.g., Luekveerawattana, 2012; Sakdiyakorn \& Sivarak, 2015; Yodsurang et al., 2016).

This research article makes an important contribution to tourism studies as follows. From the theoretical perspective it offers an alternative way to understand the authenticity of food experience, in which agents involved in tourism experiences (in terms of production, promotion, and consumption) reciprocally participate in shaping the concept of authenticity. The study of the authenticity of culinary experiences in Thailand is scarce when compared to other types of experiences, especially ethnic tourism (e.g., Dolezal, 2011; Kontogeorgopoulos, Churyen, \& Duangsaeng, 2015; Walter, 2015). Additionally, this article is exceptional in that it discusses in detail the process of mediation between tradition and modernity that occurs to the food products. Moreover, it enlightens the cultural study of Thai food through exploring the impacts of tourism on the Thai gastronomic identity in the 21st century. Thai gastronomy is not static, but subject to continuous construction (Pangkesorn, 2013). Tourism is an influential factor that contributes to placing Thai eating culture in a new fashionable stage of development (Van Esterik, 1992; Yasmeen, 2000).

In terms of the practical contribution of this article, understanding the meaning of food experiences articulated by tourism stakeholders provides a useful insight into national Thai tourism policy in which food increasingly gains momentum (Jewcharoensakul, 2013; Prachachat, 2016; Tamsingh, 2017). This article can provide beneficial insights for tourism practitioners in Thailand to develop and improve the quality of experience in the traditional market. The fact that traditional markets have become a competitive business model in the 21 st century (Cohen, 2016) means creativity can be a tool to distinguish a traditional market from others. Studies conducted by Sakdiyakorn and Sivarak (2015) and Wattanacharoensil and Sakdiyakorn (2015) suggested that enhancing the 
traditional character in tourism experiences can be an innovative strategy to develop the uniqueness of the attraction. This article expands this topic of study by focusing on the role of the authentic food experience in developing tourist attractions in Thailand.

\section{Literature Review}

This literature review considers work relating to authenticity and food tourism and sheds light on gaps in research. The experience of food had formed a part of tourism for many years (Yeoman, McMahon-Beattie, Fields, Albrecht, \& Meethan, 2015) but it was only in the late 20th century that food received specific attention as having potential to become a tourism attractor on its own. Nowadays food not only reflects the tourists' specific interest (Hall \& Mitchell, 2005; Long, 2004; Smith $\&$ Xiao, 2008) but also marks the rising significance of tourism as an experience (Quan \& Wang, 2004). According to Everett and Aitchison (2008), local food can enhance the attractiveness of the destination as well as stimulating tourist receipts.

\section{Authenticity and the Tourism Experience}

Authenticity has been an important concept widely used to analyze and assess the tourism experience. Nevertheless, its exact definition is not easily discernible given various approaches to the term. Early definitions of authenticity are related to the failure of tourism to portray genuine culture and tradition, or an escape from an inauthentic working life (e.g., Boorstin, 1964; MacCannell, 1973). According to MacCannell (1973), tourism is about "staging culture" to meet with tourist expectations and desires rather than attempting to present genuine accounts of tradition.

More recent work has moved towards treating authenticity as a reflection of the worldview of stakeholders. N. Wang (1999) introduced the concept of existential authenticity, in which authenticity evolves from how tourists interpreted the meaningfulness of their tourism experiences (see Jiang, Ramkissoon, Movondo, \& Feng, 2017; H. Kim \& Jamal, 2007; Steiner \& Reisinger, 2006; Tiberghien, Bremner, \& Milne, 2017). The distinction between authentic and inauthentic experience should be regarded as tourists' perception rather than the ability of tourism to portray objective reality (Knudsen $\&$ Waade, 2010). Authenticity should be assessed in terms of whether the destination enables tourists to evoke the image of the past (Mura, 2015). In addition to this, authenticity is to be assessed in terms of the production cycle of tourism experience: the relationship between tourism developers and tourists at the destination. This suggests that, besides the tourists, the worldviews of the host community, who create and deliver tourism experiences, play an important role in shaping the authenticity of tourist experiences (Boonzaaier \& Wels, 2017; Di Domenico \& Lynch, 2007; Tiberghien et al., 2017; Tucker \& Lynch, 2005; Zhu, 2012). In this stance, authenticity is not simply a matter of perception but also construction; in other words, authentication is a process (Cohen \& Cohen, 2012; Xie, 2011). According to Y. Wang (2007), authenticity is not only about responding to tourists' specific needs but also the desires of the hosts.

As postulated by Zhou, Zhang, Zhang, and Ma (2015), the authenticity of tourism experience is a product of the social climate in a given tourism scenario in which the host's perceived impacts from tourism and power relations among local residents affect the authentic quality of tourism experiences. Therefore, it can be concluded that synergies between the worldviews of tourism developers and tourists can contribute to the success of the destination (Brida, Disgena, \& Osti, 2012; Tucker \& Lynch, 2005). According to Fu, Kim, and Zhou (2015), successful negotiation of tourism experience can enhance tourists' perception of traditional quality in experiences.

Historical authenticity is a quality desired by many tourists (Lau, 2010). It can enhance the commercial value of toured objects (Mura, 2015), and can ensure visitors' loyalty to the destinations (Casteran \& Roederer, 2013). In many instances, traditional historical qualities are seen to be more attractive than contemporary ones (Yeoman, Brass, \& McMahon-Beattie, 2006), and the presence of modern elements are regarded negatively by tourists (Tiberghien et al., 2017). In particular, experiencing premodern society is highly attractive for some urban tourists, for whom the escape from the modern way of life is the key purpose of their travels (Taylor, 2001). 
Recent tourism literature reports the role of tourism in contributing to cultural preservation (Boonzaaier \& Wels, 2017; Leong, Takada, \& Yamaguchi, 2016). This helps to demonstrate that culture is not fixed but adapts according to circumstances (Shepherd, 2002). As shown by de Azeredo Grünewald (2006), tourism can elevate the value of local culture from being a part of ordinary routine to a highly sought-after item. The reproduction of tradition in the context of tourism reflects the process of how ancient culture is appropriated in the contemporary context (Salamone, 1997). Adaptations of local tradition are seen as a positive action to increase the attractiveness of tradition in contemporary times (Yeoman et al., 2015) and can ensure customer loyalty to the destination.

\section{Authenticity and Food Experience}

A strong relationship between food and the authenticity of the destination can be detected in existing tourism literature. Local food can contribute to the authenticity of the tourism experience due to its ability to form an integral part of the cultural image at the destination (Everett \& Aitchison, 2008; Forga \& Valiente, 2017; Mura, 2015; Mura \& Lovelock, 2009; Tiberghien et al., 2017). Traditional cuisine plays an important part in visitors' experience at the destination. Discovering local food and drink is an objective for tourists visiting the destination. In addition, the traditional quality of food is associated with the idea of otherness. For Boniface (2003), culinary tourism has developed as a reaction to the growing standardization: people are motivated to appreciate cultural diversity and have a yearning for traditional society. According to Sims (2009), the value of traditional food is articulated on the basis of difference from the urban lifestyle. Authenticity of food experience results in tourists' positive impression of the tourism experience (Jang, Liu, \& Namkung, 2011), and as such contributes to the commercial success of the destination (Parsa, Self, Njite, \& King, 2005).

Among the very few publications on food authenticity in Thailand is the study conducted by Walter (2015), who demonstrated how the authenticity of Thai food experience operates in the context of international tourists, in which the worldviews of tourists are central to the analysis. There is also a study conducted by Porananond (2015), who explored the authenticity of "Khun Tok," a northern style traditional dining experience, by focusing on the narratives generated from observation and historical development of northern Thai cuisine.

It is found that visitors express different degrees of interest in discovering traditional cuisine. According to Ozdemir and Seyitoglu (2017), tourists can be divided in terms of the desire for authenticity: authenticity seekers, moderates, and comfort seekers. Cohen and Avieli (2004) reported that tourists' willingness to escape the comfort zone impacts on how tourists engage with local food culture. Moreover, visitors engage with food for different purposes. It should be remarked that those people who are genuine culinary enthusiasts are concentrated among a group of people who possess appropriate social, economic, and cultural capital enabling them to appreciate local food while traveling (Everett \& Aitchison, 2008; Y. G. Kim, Eves, \& Scarles, 2009; Mitchell \& Hall, 2003). Fields (2002) reported that visitors are motivated to experience food at the destination due to physical, interpersonal, and social status factors. Y. G. Kim et al. (2009) classified tourist motivations to experience local food as multidimensional, which includes the tourists' profile, the appeal of the tourist attraction, as well as the attitudes of tourists with regards to food. It is found that, under certain circumstances, modification of traditional cuisine to respond to the contemporary standard is viewed as a positive approach (Burgess, 2014). Innovation is introduced in the reproduction of traditional cuisine to enhance the attractiveness of food experiences (Gunasekara \& Momsen, 2007).

The authenticity of the culinary experience can be viewed from the existential approach. It is not only about faithful portrayal of traditional food culture but rather based on the ability of food experiences to form a part of meaningful experiences in the eyes of tourists. In this respect, authenticity of food experience can be gauged from how tourists actively engage in culinary experiences. Walter (2016) related authenticity to how tourists actively justify their engagement with Thai culture through participating in cooking Thai dishes in a culinary school in Thailand. In parallel, this existential 
approach relates to the constructive approach: some culinary products are outcomes of the process of authentication, where storytelling is used to enhance the attractiveness of the products (Fox, 2007; Stoilova, 2015).

Food authenticity is not only built on tradition but contemporary culture can also construct the authenticity of the culinary experience (Chaney \& Ryan, 2012; Hall \& Mitchell, 2002; Hashimoto \& Telfer, 2006; Wilk, 1999). Authenticity reflects the ability of destination developers to deliver unique culinary experiences for tourists. As postulated by Seo, Yun, and Kim (2017), it is important for tourism destination to develop cognitive images of food experiences, which should be promoted to enhance visitors' perception of authenticity. It should be noted that tourism experiences not only concern the consumption of food and drinks, but also encompass tourists learning about local culture (Smith \& Xiao, 2008). Moreover, the value of food experiences embraces other elements that complement culinary experiences (Y. G. Kim et al., 2009). According to Jang et al. (2011), atmosphere plays a significant role in the authentication of culinary experiences.

The central objective of this article is to analyze how tradition and modernity are negotiated in the context of authenticity and food in Thailand; the processes of the creation, promotion, and consumption of food experiences are key to this. The review of existing literature indicated that there are gaps in research on this subject, which this research project article is helping to fill, and areas that need further development, specifically: food tourism and authenticity in Thailand, and the engagement of multiple stakeholders in the creation of that authenticity.

\section{Research Methods}

The research was qualitative and it follows the postpositivistic paradigm in that it uses small samples with rich subjective data in order to develop theory (cf. Hussey \& Hussey, 2003). Broadly, it is constructivist, believing that people construct knowledge and meaning from experience and relationships. The research aimed to grasp the emic perspectives of stakeholders towards the authentic presentation of traditional culinary experiences.
It also aimed to understand the social phenomena that have an impact on the stakeholders' perception of authenticity. Methods used were semistructured interviews and questionnaires with open-ended questions. Observation of the markets by the researcher was also undertaken to assess the usage of the market space, the characteristic of culinary products sold, and the behavior of food sellers and food visitors.

Research on which this article is based is comprised of short studies of eight traditional markets in the central region of Thailand: Khlong Lad Mayom Floating Market, Talingchan Floating Market, Gong Khong Market, Ayothaya Floating Market, Bang Nampheung Floating Market, Samchuk Hundred-Year Market, Amphawa Floating Market, and Pattaya Floating Market. These markets were chosen as representative of floating markets in the broader Bangkok region, based on information supplied by the Tourism Authority of Thailand, supported by comments from personal contacts in the region.

Fieldwork was conducted in two rounds: December 2012-March 2013, and January 2014-March 2014. The latter round intended to record changes that might have occurred after the first round of data collection and obtain additional information. In total, some 80 market food traders and 17 market management officers were interviewed. Fiftyeight visitors completed questionnaires (or were interviewed); they included men and women aged between 18 and 70 and were from a wide range of backgrounds such as students, teachers, office workers, entrepreneurs, engineers, and a railway employee; only three were from overseas countries (China, UK, and Ireland), and the rest were from Thailand. On both rounds of the research, all participants were asked about how they view traditional culture and food experiences in the traditional markets. The mixed-method combination of qualitative interview, open-ended questionnaires, and observation enhanced trustworthiness in data collection.

Full verbatim transcription was operated to transcribe audio-recorded data. According to Thomas and Harden (2008), thematic analysis is an effective way to systematically synthesize data based on people's worldview and can enhance transparency in the process of reporting the data. The data from 
both the first and the second round of the research project were analyzed according to themes set before the field research.

To address shortcomings in the time and budget, convenient sampling was used in selecting food vendors and visitors (see Kelley, Clark, Brown, \& Sitzia, 2003). However, when applicable, snowball sampling was used to reduce the degree of bias of the researcher in choosing interviewees. Recommendations from previous food vendors and visitors involved in the research project were used to identify possible participants. Purposive sampling was used in choosing participants representing the management officers from each market. The population of visitors was in the majority from Thailand as it was difficult for the researcher to obtain opinions from non-English or Thai speakers due to the language barrier. Furthermore, many foreign visitors came as tour groups and did not have much free time to visit the market on their own. This limited the research to focus mainly on domestic tourists.

It is accepted that an element of subjectivity enters into fieldwork, reflecting how the researcher engages with the research (McDaniel \& Gates, 1999; Punch, 1998). The field researcher was born and raised in Thailand, which has helped in the understanding of the value of traditional food cultures from a local perspective.

\section{Research Findings and Analysis}

This research project reveals that the authenticity of culinary experiences in terms of the negotiation between tradition and modernity can operate in many dimensions. This is in line with the views of Y. Wang (2007) and the concept of customized authenticity, but importantly, it moves the understanding in a new direction: it is not only about complying with the needs of the tourist industry but also reflects the hosts' interpretation of culture. Moreover, the diversity of tourists also contributes to multiple interpretations of culinary experiences in the traditional market. All agents (market officers, food traders, and visitors) play a crucial part in shaping the authenticity of culinary experiences, as illustrated in Figure 1.

Many traditional markets benefit from their own local natural and built environment (e.g., traditional houses along the water, traditional commercial

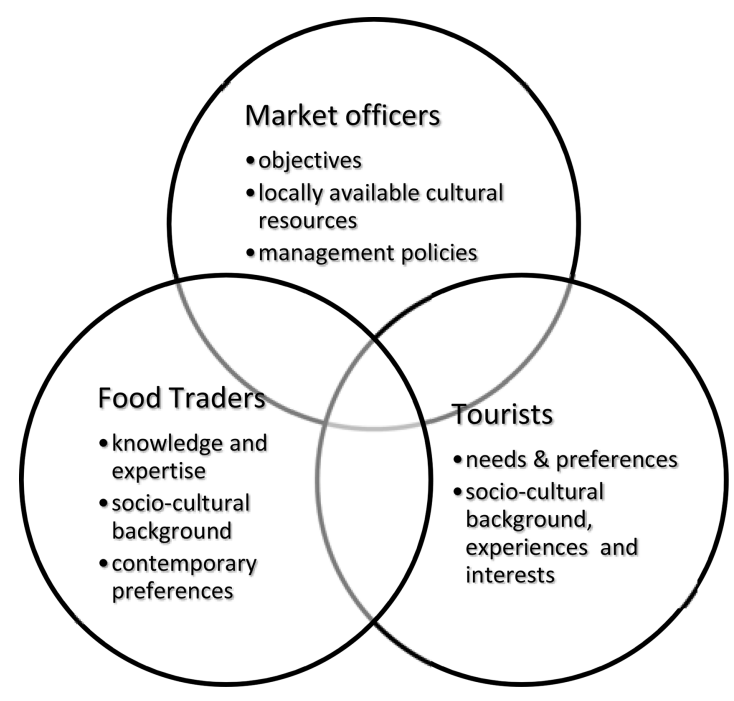

Figure 1. The authenticity of culinary experiences as a combination of stakeholders' inputs.

buildings, old-fashioned food stalls, fruits and vegetable orchards, Buddhist temples). However, there also exist a number of recently constructed traditional markets, intentionally built according to the initiatives of the management team to depict the traditional Thai way of life (e.g., Gong Khong Market, Ayothaya Floating Market, and Pattaya Floating Market).

Traditional culture is integrated into tourist activities provided in the market (e.g., boat excursions to contemplate the scenery of the market, elephant riding, local events, and fairs) and commodities sold in the market (e.g., traditional handicrafts, old-fashioned utensils and decoration items, local plants, traditional cosmetic products). In terms of culinary experiences, traditional culture is visible in food products sold in the market (e.g., old-fashioned food, locally grown crops, food products produced by peasants) and culinary-related activities in the traditional markets (e.g., visits to local farms, boat excursions to gastronomic villages, culinary museums, culinary demonstrations).

\section{The Market Officers}

The officers of the traditional markets regard the traditional Thai culture as a principal element in the creation of tourism experiences; although, officers of each market have different ideas about 
the traditional culture that is presented in the market. Their interpretations of the traditional culture depend on the relationship between traditional markets and the local communities.

The relationship between the market officers and the market traders can be divided into formal and informal. Officers set criteria for the recruitment of traders, which may include being a local resident. Market regulations also govern the activities of the traders, such as: conduct, hygiene, culinary methods, production of food, and participating in meetings. Traders themselves may promote the market and make the marketplace attractive. Informally the officers make recommendations to traders; for example, concerning cuisine, and undertake research into possible products. Reciprocally, local traders influence the ideas of officers concerning items for sale and related activities.

Nevertheless, it is important for the traditional markets to follow the tourists' preferences, which are partially shaped by modern consumer preferences. The value of traditional culture in food experiences expressed by the management team of the traditional markets is explored below.

The management team rely on different aspects of their resources in the construction of a traditional cultural image: traditional agriculture, old-fashioned way of life, ethnic culture, and the history of the community. The cultural image presented by the management team determines the character of culinary experiences.

The manager of Gong Khong Market (Kung, 2012, personal communication) explained that the market is established with the purpose of reviving characteristics of an old-fashioned market. The unpleasant aspects of modern markets in larger cities, where some traders behave rudely to visitors, inspired her to create a trade space where positive values associated with peasants are conserved, besides reviving the trade history in the area. The physical components of the market are stressed (décor of the market that depict the ancient trade including low-rise stalls and a series of open houses with thatched rooves). She insisted that traders in the market must be supportive of her vision to conserve traditional culture: they are required to dress in the traditional Thai costume and encouraged to sell old-fashioned dishes and must be friendly to all visitors. Importantly, they must be sincere with the quality of food products offered to visitors by using ingredients and cooking methods that do no harm.

The cultural value of food constitutes an important aspect of the relationship between the market and the locality, it is considered as an attribute contributing to the genuineness of the traditional culture. The fact that the traditional markets are capable of depicting heritage that represents the history and culture of the community enables them to stand out from their modern counterparts, giving them a competitive advantage as suggested below:

\begin{abstract}
One of our competitive advantages is that we are presenting the authentic way of life, in contrast to some places like Pattaya Floating Market in Chonburi. They simulate cultures from four different regions of Thailand. There is no one actually living there. However, Samchuk is a real home. . . . The difference between Samchuk and other markets is that our market is not a new creation. We don't aim to simulate traditional markets. It retains its original structure and has remained the same since we were born. (The Board of Samchuk Community, personal communication, 2013)
\end{abstract}

In some traditional markets contemporary-style food is recognized by the management team as a culinary specialty of the market. This can be exemplified by the custard bread sold by food traders in Ayothaya Floating Market. In certain cases, the presence of contemporary consumer culture is appropriated as part of the local history by the management team. In traditional markets such as Gong Khong Market, the availability of contemporary-style food items is interpreted as invention brought by foreign traders who came to Ayuthaya at that time:
Although Gong Khong Market positions itself as a traditional marketplace, food does not have to be traditional. You can see that some food items sold in the market are modern ones. That is, according to the Thai history, new food items can come by ship. (Owner and manager, personal communica- tion, 2014)

The influence of modern culture in the traditional markets is represented by visitors' expectations, which, in many cases, is not confined to the accurate presentation of traditional culture. Some traditional markets chose to present aspects of traditional culture that are thought to be popular among visitors. 
In addition, the commercial interest can be seen from how the management team of the traditional markets say that the commercialization process is not always a threat to the value of traditional culture but rather should be encouraged, so as to enhance the public awareness of culinary heritage:

The commodification of culture does not threaten the culinary uniqueness of Ayuthaya. Rather, local food products become more significant as specialties of the market. Well, there are many of them here in Ayuthaya. You can see plenty of RotiSaimai available for purchase in the city. Once this market is established, food vendors bring the products for sale in Ayuthaya. (Gomin, personal communication, 2013)

\section{Food Traders}

Old-fashioned food products form the majority of edible items sold in the traditional markets. Traders incorporate traditional recipes and local know how in the production of food. A number of traders choose to sell old-fashioned products that are rare today. In many cases, the usage of traditional recipes and traditional markets is justified as a means to enhance the quality of food experiences. The identification of food products as culinary specialties of the community or the region, and the identification of products as One Tambon One Product (OTOP, a local-level socioeconomic development initiative) are among the communication strategies used by food traders.

Storytelling is also used by some food traders who market their products by establishing a connection to certain aspects of local history. An obvious example can be seen from Lek Arunee, a sweet trader in Amphawa Floating Market who connects food products to the boat poetry song composed by King Buddha Loetla Nabhalai (1809-1844), whose former residence was in Amphawa district. Authenticity of experiences or the accurate presentation of traditional food culture (or local foodways) is in general regarded by traders as an important attribute that can enhance the commercial value of food.

Food traders interpret the idea of traditional culture in the development of food commodities for sale. They rely on different resources including: family heritage (e.g., recipes), local food heritage (e.g., local recipes), local history (e.g., poetry and song with desserts), and education (formal and informal) in the production of traditional food products.

There is a connection between the performance of food products in terms of sales success and the sociocultural background of traders. Notably a number of food traders in the traditional markets received higher education and have knowledge and experience in marketing. This group of traders are usually young adults (aged 20-40 years old) who were educated outside communities and spent some time living outside the communities. They operate their own food stalls or assist parents. When compared to the older generation of food traders, they are more capable of offering successful food products. Many well-known food stalls in the traditional markets belong to them. They know how to convert traditional food know how into successful commercial products consumed on sites, as well as ways to promoted old-fashioned food to attract younger people:

Food products should be handmade and have their own signature. There should be food products that are designated as culinary specialty of Samchuk. (Roongroj, food trader, personal communication, Samchuk Market, 2013)

The traditional know how is seen by traders as a means to enhance the physical quality of food recipes and cooked products. In many cases, the usage of traditional methods is intended to intensify visitors' food experiences through visual perception, as justified by a grilled pork trader in Khlong Lad Mayom Floating Market:

Normally, we use an oven to grill pork. Here we use the charcoal cooker because people are more attracted to old-fashioned cooking methods. They tend to buy old-fashioned food rather than contemporary food. In the stall, customers will see that dried grilled pork is genuinely traditional. (Boonnam, personal communication, 2013)

The influence of modern consumer culture can be observed from how food traders attempt to modify the recipes of old-fashioned food to suit visitors' tastes. For many food traders the adaptation of old-fashioned food in terms of production (e.g., modification of recipes) and presentation (e.g., the promotion of food based on elements of the local history, the usage of modern-style packaging) is 
important in making food attractive, especially for younger visitors.

\section{Tourists and Their Experiences}

Tourists engage in culinary experiences in the traditional markets in many ways, including the consumption of food at the market, the purchase of take-away food and raw food materials for household use, the participation in culinary events, and culinary workshops. The sociocultural background of visitors influences how they perceive the cultural value in the traditional markets. The age of visitors and their places of origin form a part of their cultural capital in interpreting the concept of traditional food. Middle-aged and older visitors tend to interpret their culinary experiences based on direct experiences with food. Younger visitors, due to the lack of knowledge and direct experiences with oldfashioned food, are inclined to have a stereotypical image of the premodern way of life.

Thai visitors (domestic tourists) are capable of appreciating a variety of traditional food when compared to foreign international tourists, who are less knowledgeable in consuming Thai food: some foreign visitors are reluctant to consume food on site due to hygiene concerns and unfamiliarity (cf. Cohen \& Avieli, 2004). Many international tourists visit the markets with a tour guide who takes them to specific food stalls in the market rather than allowing visitors to explore the food scene in the market at will.

At the same time, the authenticity of culinary experience should be considered in relation to the contemporary context. It is important for culinary experiences to correspond with the contemporary preferences and current sociocultural trends. Moreover, the diversity of tourists in terms of sociocultural background and the willingness to engage in traditional culinary experiences should be taken into account. That is, visitors exhibit different degrees of "neophilia" (factors encouraging tourists to expose themselves to the local food), and its opposite "neophobia" (Cohen \& Avieli, 2004), upon exposure to food in the traditional markets.

Visitors expressed diverse interests with regards to traditional food products in the markets, which can be divided into four categories: 1) interested in discovering traditional and local gastronomy;
2) interested in food but not limited to traditional and local products; 3 ) interested in traditional and local way of life, which is not limited to food; and 4) visitors without a particular interest in food or traditional culture. This shows that other factors apart from gastronomic interest play a part in visitors' assessment of food experiences on these sites. Moreover, while food experiences are often valued based on the extent to which they are related to the traditional way of life, contemporary culture plays an important role shaping visitors' food experiences.

Traditional culture is viewed by local and nonlocal visitors as an important component in their experience in the traditional market. The search for authenticity in terms of the accurate depiction of the traditional way of life has attracted visitors to the traditional markets. As one visitor to Amphawa Floating Market stated:

I love the atmosphere of the market. I love those old wooden building. I love traditional markets that are developed from authentic communities, not the ones that are entirely built up to imitate traditional culture. (Tianxin, personal communication, 2013)

Visitors discern the cultural value of food based on the relationship between food and certain aspects of the local way of life including local tradition, local history, traditional agriculture, and the involvement of community residents in the production and promotion of food. The value of traditional food can also be associated with rarity. This is often seen in visitors who live in Bangkok who choose to buy oldfashioned items in the traditional markets because they cannot be found in their neighborhood.

Visitors are found to be able to relate their culinary experience to the cultural image promoted by the traditional market. As stated by Nanta, a visitor from Gong Khong Market: "Food is authentically traditional and local because they are peculiar and also they are related to Ayuthaya kingdom" (personal communication, 2014). According to Nawin, a visitor from Amphawa Floating Market: "Food is authentically local because Amphawa is an ancient market and food products are compatible with the appearance of the market" (personal communication, 2014).

The concept of traditional culture is often interpreted in terms of personal memories, derived from 
visitors' direct experiences of old-fashioned food during their childhood, and personal interests in rediscovering ways of life that existed in premodern times. This is visible by a visitor's justification of her food choices in Bang Nampheung Floating Market: "I love fruits and dishes that are made by elderly people because they make them in an oldfashioned taste" (Kamolporn, personal communication, 2013).

Visitors associate the quality of traditional food products with superior taste, and it is believed by traders that usage of old-fashioned recipes adds a superior flavor to food. The quality of old-fashioned food is associated with the preindustrial production of food. The idea of homemade food is described as the usage of high quality ingredients and traditional cooking methods that results in better taste. Visitors also value traditional food products as a healthier food option, they justify the purchase of traditional edible items based on herbs that provide a superior quality of nutrition.

For many visitors interviewed, the taste of food is prioritized over its cultural content. An explicit example can be seen from a visitor in Amphawa Floating Market (Bukori, aged 25, 2013) who reported that he will not purchase food items that taste bad even though they are identified with the local tradition. This indicates that it is hard for traditional food products that fail to meet the modern palate to commercially survive in this type of touristic attraction.

Culinary experience in the traditional markets is also assessed by visitors on the basis of how it enables them to escape from the daily routine: the consumption of food on site is seen as a relaxation activity. The cultural identity of food is less appealing than the ambience of the market, described as the natural scenery and the local tradition offered on site, which gives the sensation of escape from the negative aspects of reality that visitors encounter in their everyday lives.

\section{Use of Authenticity in the Traditional Market}

Research findings show that the concept of authenticity is important in the production, promotion, and consumption of food experiences offered in the market. Efforts to portray and give experiences of authentic traditional food culture are visible relating to the views expressed by the management officers, food vendors, and visitors in the traditional market (see Table 1). Authenticity serves as a factor that complements the quality of tourism and thus differentiates one food experience from another: it adds value to the product. The success of the traditional markets in offering authentic food experiences results in visitors repeating their visits. This aspect of the tourism experience demonstrates that authenticity can be viewed as having an objective value (see Lau, 2010): it is a desirable value that many stakeholders want to acquire.

The authenticity of food experiences offered in traditional markets is an outcome of the interactions between stakeholders. The creators of tourism experiences and the visitors reciprocally contribute to the articulation of the concept of authenticity in

Table 1

Stakeholders Views on Authenticity and Related Usage in the Food Markets

\begin{tabular}{lll}
\hline Stakeholder & \multicolumn{1}{c}{ Views on Authenticity } & Related Usage in the Market \\
\hline Market officers & $\begin{array}{l}\text { Traditional cultural image (e.g., traditional way of } \\
\text { life, ethnic cultures, historical material belongings) }\end{array}$ & $\begin{array}{l}\text { Low-rise stalls, thatched roofs; Traditional } \\
\text { costumes; Open houses; Policy on food } \\
\text { sales and service }\end{array}$ \\
Traders & $\begin{array}{l}\text { Old fashioned food products } \\
\text { Accurate presentation of traditional food }\end{array}$ & $\begin{array}{l}\text { Traditional recipes, local know how } \\
\text { Local specialties, story-telling associated with } \\
\text { traditional foods; Hand-made food products }\end{array}$ \\
Visitors & Experience relating to childhood \\
& $\begin{array}{l}\text { Traditional culture accurately depicted } \\
\text { Rare or unusual items }\end{array}$ & $\begin{array}{l}\text { Food made with an old-fashioned taste } \\
\text { Traditional wooden buildings } \\
\text { Local people involved in production and } \\
\text { promotion of food }\end{array}$ \\
\hline
\end{tabular}


this tourism scenario. For "experience" developers (market officers and food traders), traditional culture is the main selling point of the markets, in which food is a means to reinforce traditional culture in the traditional markets. The creation of food commodities and culinary-related experiences in the market contributes to visitors' validation of authentic experience. At the same time, their preference for certain aspects of tourism experience is important and goes on to influence the tourism developers' creation of tourism experiences. This demonstrates that visitors participate in the development of the concept of authenticity, as well as ultimately consuming it through their experience, which includes eating the food. Agents define the concept of authenticity from values and beliefs that are personal to them and those they acknowledge as belonging to a locality. Therefore, they are active in the development of authenticity through their cultural capital and actual authentication of their culinary products. The following points elaborate on the above statements.

For certain market managers, the personal preference is translated into the presentation of traditional culture in the traditional market. As expressed by Kung, the market manager of Gong Khong Market, her passion for traditional Thai culture of the central region is behind the creation of the market.

For food vendors, personal memories play an important role in the cultural expression of culinary experiences in the traditional market. Culinary items sold in the market can be seen as a reflection of knowledge and skills that belongs to the familial and cultural root of vendors. Personal values and beliefs play a significant role in the stakeholders' articulation of authentic tourism experiences including childhood memories.

Authentic culinary experiences in the traditional markets are also related to the cultural identity that is shared among people in the community. Traditional culture that belongs to the local area is a source for market managers and food vendors in creating culinary experiences. In traditional markets that have a more distanced relationship with residents in the community, experience developers choose to promote food products by identifying with national culture.

Collective heritage functions as a cultural reference for visitors who lack direct experience with old-fashioned food. Teenage and young adult visitors rely on the character of the national Thai culture and traditional food products that have been promoted as main selling points in the traditional markets. The consumption of traditional culture by the young generation can be viewed as part of the rise of vintage or retro fashion in the Thai society, which partly explains the growing popularity of old-fashioned food products. The "old fashioned" is viewed not only as an aesthetic but also a quality enhancer; that is, authentic traditional gastronomic items sold in the traditional markets are perceived as having superior quality in terms of nutritional values and taste.

\section{Authenticity as a Contemporary Expression of Cultural Heritage}

The authenticity of food products offered in the traditional markets is not an effort to make an accurate portrayal of culture that existed in premodern times, but rather, it reflects how traditional Thai culture is reinterpreted in the present time, dominated by modern culture. This is an example of how heritage is the interpretation of the past through the lens of the present (see Lowenthal, 1998; Sutton, 1998; Tunbridge \& Ashworth, 1996).

At the same time, the process of authentication should be viewed as a selection process, and in addition, the enhancement of a product for consumption. The significance of authenticity in the production, promotion, and consumption of traditional food products demonstrates that the flow of time does not reduce the importance and relevance of old-fashioned culture, but rather ascribes new value to it.

The cultural expression of traditional food culture goes beyond what is defined as knowledge of the locale. The traditional markets do not restrict the character of food products sold on site, or the origin of traditional culture: traders can bring food culture that originates from other locations. A number of food vendors interviewed stated that they use recipes inherited from their family who are nonlocal dwellers in the community. In addition, commercial viability also influences vendors' choices of traditional culture. Many traders choose to sell nonlocal traditional food products that are popular among the general public. To an extent, 
the importation of nonlocal traditional food culture compensates for the lack of local culture in certain traditional markets. Time (in the sense of history) plays a more important role in visitors' perceptions of traditional culture in the traditional markets than space (in the sense of geographical location).

Authenticity functions as an important value upheld by stakeholders, but does not indicate that all aspects of traditional culture are embraced in modern times. Certain traits of traditional food items are viewed as undesirable by a number of participants in the market. The growth of health concerns in Thai society has resulted in occasional denouncement of certain traditional food products. Traders modify the original food recipes to suit contemporary preferences, as seen in the reduction of the sugar content. It is also found that traditional food recipes are intentionally adapted to attract visitors. This can be seen in the diversification of flavors of traditional food.

The adaptation of global culture for local use (glocalization) is visible in food products sold in the market. According to some traders interviewed, non-Thai food goods are adapted to suit the local palate. Under certain contexts the production and sales of Western food is counted as local expertise. It should be remarked that gastronomic culture is constantly dynamic, resulting in certain aspects of Western gastronomy being adopted as local diet (Van Esterik, 1992). Research findings showed that certain visitors identified culinary experience in the traditional market with the surrounding of the traditional market, rather than with the character of food products.

The fact that many food vendors and market officers receive a high education and are equipped with knowledge and skills in marketing leads to constant improvements in food experiences offered in the market. Traditional food recipes are adapted to suit contemporary consumption trends. The traditional market is a popular attraction because it can respond to the Thai way of life in the 21st century: the growing demand for budget leisure experience and the growing interest in the consumption of oldfashioned commodities.

Commercial interests, while contributing to the creativity of food experiences, can limit the diversity of food culture promoted in the market. Food vendors' interest in securing commercial benefit can result in their decision to sell food products that have been popular in the traditional market. The age and the nationality of visitors are obstacles in the consumption of food experiences. A lack of direct experience with traditional food culture limits the younger Thai visitors' appreciation of traditional food culture in the market. This can be seen from how they tend to identify authentic food culture with stereotyped traditional food culture. Furthermore, non-Thai international tourists have limited cultural capital to appreciate local Thai food experiences, and the nature of their visits can limit their experiences in the market. A large proportion of this type of visitor come with a tour guide who takes them to specific eateries, and visitors are unable to freely explore the market's food at will.

\section{Conclusion}

This article investigated how the concept of authenticity is involved in the process of the creation, promotion, and consumption of food in traditional markets in Thailand, as well as the ways that stakeholders interpret the concept of authenticity and use it in their activities. Research conducted involved two periods of fieldwork, each lasting around 3 months in Thailand, during which 17 market officers, 80 traders, and 58 visitors were interviewed or answered questionnaires. Observation of the markets was also undertaken.

Earlier sections have discussed in detail how research indicated that authenticity can be a unique selling proposition, offer competitive advantage, and be influenced by contemporary culture. Traders are shown to use authenticity, employing local resources, family history, and knowledge to their advantage. Visitors bring their own personal experiences to bear on their perception of authenticity at the markets and value the traditional ambience of the venue as well as the food, and so authenticity becomes something that enhances the quality of the visitor experience. The expression of authenticity of culinary experiences in the traditional markets has been shown by research to be mediated by the relationship between the past and the present, because the presentation of traditional food culture is a reflection of how the traditional is perceived today.

Research findings have shown that authenticity, in terms of traditional food, has been constructed 
by stakeholders, especially the market officers and traders. This authenticity may differ through the products according to the personal experiences and motivations of the agent involved. Moreover, the visitors' experiences and expectations impact on the final product, in an evolving scenario. The social context of contemporary times also impacts on the product, creating a synergized result. One specific aspect of this case study is that the "traditional" experience is something that some older visitors can actually remember from their childhood. Therefore, these people can verify (to a degree) the authenticity of contemporary versions. Other visitors have less capability, especially foreign visitors.

Such a situation outlined above illustrates the fundamental relativity of authenticity as a personal experience, and also as a thing that can be constructed. There is a continuum of authenticity, a scale in which authenticity can vary. This is also demonstrated by the markets themselves, some of which are original, whereas others have been built recently. Authenticity in this sense is a fluid concept, one capable of multiple variations and interpretations. For despite being embraced within the concept of "objective authenticity" as gastronomy (Zhou et al., 2015, p. 35), traditional food in Thailand can never be absolutely authentic - one would have to travel back in time to the premodern period to experience that. Therefore, the statement that "authenticity is a concept that derives its meaning only through the positing of its opposite" (Zhou et al., 2015, p. 29) does not do the subtle and fluid nature of authenticity justice: there are many degrees of authenticity, from zero to $100 \%$. Authenticity is a relativistic concept when referring to phenomena such as intangible heritage which are subject to sociocultural change in time and space.

This study is the first to deal with traditional markets in Thailand focusing on the use of authenticity by stakeholders. It gives the emic perspective of the local hosts concerning authenticity and describes how they use the idea of authenticity in promoting their food products. Research demonstrates the proactive engagement of the stakeholders with the idea and manifestations of authenticity as it relates to food; moreover, it proves the multiple inputs into this complex process involving market officers, traders, and visitors. The richness of the data help to illustrate how various are the aspects of authenticity in this context, the empirical evidence supporting our conclusion concerning theoretical aspects of the concept. In this sense our work adds to the small but growing corpus of research into host communities and authenticity. Importantly, analysis of the findings has led us to call for a recognition of the diversity of meaning concerning authenticity, and its fundamental quality of gradation when part of a sociocultural context. Furthermore, the vital part played by host communities has formed the major focus of this project, and there is a need for more research into host communities, their understanding of authenticity, and their uses of it in their working lives.

Despite the fact that authenticity is embraced by different stakeholders in the traditional markets, the cultural aspect of food is still poorly promoted and perceived in the traditional market due to the private nature of gastronomic knowledge in the local areas. Food knowledge was orally passed down from generation to generation. The fact that this type of knowledge is often treated as a secret can result in the disappearance of such knowledge once experts refuse to transfer their knowledge and skills to the next generation. Therefore, this is another area of future research that will help to record and perhaps protect such vulnerable traditional knowledge.

Our research indicates that traditional food may be further promoted as a tourism offering in the traditional markets of Thailand by means of stimulating visitors' engagement in food culture. More effort is needed in the promotion of culinary experiences and activities. Authenticity, as it relates to food tourism in traditional markets, is not a matter of preserving culture in its pristine stage, but rather, is a creative process driven by the host stakeholders, making the value of traditional culture remain meaningful in contemporary times.

\section{Acknowledgments}

This research article would not have been completed without support from the management team of each traditional market. They granted us permission to conduct research on site as well as supplying us with useful data and insights regarding culinary experience in Thailand. We are also grateful to the people who work for the Tourism Authority of 
Thailand for taking part in the interviews, including Khun Siripakorn Chewsamoot, former director of TAT Office London Branch, and Khun Jaruchet Ruangsuwan, assistant director of the department of Tourism Products and Business Groups at the TAT headquarter. Many thanks go to Khun Worapa Angkasirisap, former assistant director of TAT Office London branch, for her advice and help to connect us with other TAT staff. Last but not least, we would like to extend heartfelt gratitude to those people on each site who participated in either the interviews or the surveys, as well as those who acted as research facilitators throughout the duration of the project.

\section{References}

Boniface, P. (2003). Tasting tourism: Travelling for food and drink. Aldershot, UK/Burlington, VT: Ashgate.

Boonzaaier, C., \& Wels, H. (2017). Authenticity lost? The significance of cultural villages in the conservation of heritage in South Africa. Journal of Heritage Tourism, 13(2), 181-193.

Boorstin, O. J. (1964). The image: A guide to pseudo-events in America. New York, NY: Harper and Row.

Brida, J. G., Disgena, M., \& Osti, L. (2012). Perceptions of authenticity of cultural events: A host-tourist analysis. Tourism Culture \& Communication, 12, 85-96.

Burgess, P. J. (2014). Modification of a traditional Korean food product (Gochujang) to enhance its consumer acceptability as an ethnic food. Journal of Ethnic Foods, 1(1), 13-18.

Casteran, H., \& Roederer, C. (2013). Does authenticity really affect behavior? The case of the Strasbourg Christmas Market. Tourism Management, 36, 153-163.

Chaney, S., \& Ryan, C. (2012). Analyzing the evolution of Singapore's World Gourmet Summit: An example of gastronomic tourism. International Journal of Hospitality Management, 31(2), 309-318.

Cohen, E. (2016). The permutations of Thailand's "floating markets." Asian Journal of Tourism Research, 1(1), 59-98.

Cohen, E., \& Avieli, N. (2004). Food in Tourism-Attraction and impediment. Annals of Tourism Research, 31(4), $755-778$.

Cohen, E., \& Cohen, S. A. (2012). Authentication: Hot and cool. Annals of Tourism Research, 39(3), 1295-1314.

De Azeredo Grünewald, R. (2006). Pataxó tourism arts and cultural authenticity. In M. K. Smith \& M. Robison (Eds.), Cultural tourism in a changing world: Politics, participation and (re)presentation (pp. 203-214). Clevedon, UK: Channel View Publications.

Di Domenico, M., \& Lynch, P. A. (2007). Host/guest encounters in the commercial home. Leisure Studies, 26(3), 321-338.
Dolezal, C. (2011). Community-based tourism in Thailand: (Dis-)illusions of authenticity and the necessity for dynamic concepts of culture and power. ASEASAustrian Journal of South-East Asian Studies, 4(1), $129-138$.

Everett, S., \& Aitchison, C. (2008). The role of food tourism in sustaining regional identity: A case study of Cornwall, South West England. Journal of Sustainable Tourism, 16(2), 150-167.

Fields, K. (2002). Demand for the gastronomy tourism product: Motivational factors. In A.-M. Hjalager \& G. Richards (Eds.), Tourism and gastronomy (pp. 36-50). London, UK: Routledge.

Forga, J. M. P., \& Valiente, G. C. (2017). Cultural change and industrial heritage tourism: Material heritage of the industries of food and beverage in Catalonia (Spain). Journal of Tourism and Cultural Change, 15(3), 265-286.

Fox, R. (2007). Reinventing the gastronomic identity of Croatian tourist destinations. International Journal of Hospitality Management, 26(3), 546-559.

Fu, Y., Kim, S., \& Zhou, T. (2015). Staging the "authenticity" of intangible heritage from the production perspective: The case of craftsmanship museum cluster in Hangzhou, China. Journal of Tourism and Cultural Change, 13(4), 285-300.

Gunasekara, R. B., \& Momsen, J. H. (2007). Amidst the misty mountains: The role of tea tourism in Sri Lanka's turbulent tourist industry. In L. Joliffe (Ed.), Tea and tourism: Tourists, traditions and transformations (pp. 8497). Clevedon, UK: Channel View Publications.

Hall, C. M., \& Mitchell, R. D. (2005). Gastronomic tourism: Comparing food and wine tourism experience. In M. Novelli (Ed.), Niche tourism: Contemporary issues, trends and cases (pp. 73-88). Oxford, UK: Elsevier.

Hall, C. M., \& Mitchell, R. D. (2002). The changing nature of the relationship between cuisine and tourism in Australia and New Zealand: From fusion cuisine to food network. In A.-M. Hjalager \& G. Richards (Eds.), Tourism and gastronomy (pp. 186-206). London, UK \& New York, NY: Routledge.

Hashimoto, A., \& Telfer, D. J. (2006). Selling Canadian culinary tourism: Branding the global and the regional product. Tourism Geographies, 8(1), 31-55.

Hussey, J., \& Hussey, R. (2003). Business research (2nd ed.). Basingstoke, UK: Palgrave Macmillan.

Jang, S., Liu, Y., \& Namkung, Y. (2011). Effects of authentic atmospherics in ethnic restaurants: Investigating Chinese restaurants. International Journal of Contemporary Hospitality Management, 23(5), 662-680.

Jewcharoensakul, S. (2013). Tourist industry promotion: Aim to introduce Thai foods matching with northern program's tours to serve sustainable tourism. In The International Conference on Tourism, Transport and Logistics, 653-661.

Jiang, Y., Ramkissoon, H., Mavondo, F. T., \& Feng, S. (2017). Authenticity: The link between destination image and place attachment. Journal of Hospitality Marketing \& Management, 26(2), 105-124. 
Kelley, K., Clark, B., Brown, V., \& Sitzia, J. (2003). Good practice in the conduct and reporting of survey research. International Journal for Quality in Health Care, 15(3), 261-266.

Kim, H., \& Jamal, T. (2007). Touristic quest for existential authenticity. Annal of Tourism Research, 34(1), 181-201.

Kim, Y. G., Eves, A., \& Scarles, C. (2009). Building a model of local food consumption on trips and holidays: A grounded theory approach. International Journal of Hospitality Management, 28(3), 423-431.

Knudsen, B. T., \& Waade, A. M. (2010). Performative authenticity in tourism and spatial experience: Rethinking the relations between travel, place and emotion. In B. T. Knudsen \& A. M. Waade (Eds.), Re-investing authenticity: Tourism, place and emotions (pp. 1-19). Bristol, UK: Channel View Publications.

Kontogeorgopoulos, N., Churyen, A., \& Duangsaeng, V. (2015). Homestay tourism and the commercialisation of the rural home in Thailand. Asia Pacific Journal of Tourism Research, 20(1), 29-50.

Lau, R. W. K. (2010). Revisiting authenticity: A social realist approach. Annals of Tourism Research, 37(2), 478-498.

Leong, C., Takada, J., \& Yamaguchi, S. (2016). Analysis of the changing landscape of a World Heritage site: Case of Luang Prabang, Lao PDR. Sustainability, 8(747), 1-23.

Long, L. M. (2004). Culinary tourism: A folkloristic perspective on eating and otherness. In L. M. Long (Ed.), Culinary tourism (pp. 20-50). Lexington, KY: The University Press of Kentucky.

Lowenthal, D. (1998). The heritage crusade and the spoils of history. Cambridge, UK: Cambridge University Press.

Luekveerawattana, S. (2012). Cultural landscape for sustainable tourism case study of Amphawa community. Procedia - Social and Behavioral Sciences, 65, 387-396.

MacCannell, D. (1973). Staged authenticity: Arrangements of social space in tourist settings. American Journal of Sociology, 79(3), 589-603.

McDaniel, J., \& Gates, R. (1999). Contemporary marketing research. Franklin, OH: Southwestern College.

Mitchell, R., \& Hall, C. M. (2003). Consuming tourists: Food tourism consumer behaviour. In C. M. Hall, L. Sharples, R. Mitchell, N. Macionis, \& B. Cambourne (Eds.), Food tourism around the world (pp. 60-80). Burlington, MA: Elsevier.

Mura, P. (2015). Perceptions of authenticity in a Malaysian homestay-A narrative analysis. Tourism Management, 51, 225-233.

Mura, P., \& Lovelock, B. (2009). A not so Little Italy? Tourist and resident perception of authenticity in Leichhardt, Sydney. Tourism Culture \& Communication, 9(1-2), 29-48.

Nartsupa, C. (1991). Thai culture and social movements. Bangkok, Thailand: Thammasat University Press.

National Statistical Office. (2016) Tourists'statistics, national statistical office of Thailand. Retrieved from http://ser vice.nso.go.th/nso/web/statseries/statseries23.html

Ozdemir, B., \& Seyitoglu, F. (2017). A conceptual study of gastronomical quests of tourists: Authenticity or safety and comfort. Tourism Management Perspectives, 23, 1-7.
Pangkesorn, A. (2013). Thai arts \& creativity: The new identity for Thai foods catering. Veridian E-Journal SU, 6(6), 31-55.

Parsa, H. G., Self, J. T., Njite, D., \& King, T. (2005). Why restaurants fail. Cornell Hotel and Restaurant Administration Quarterly, 46(3), 304-322.

Pongajarn, C., van der Duim, R., \& Peters, K. (2016). Floating markets in Thailand: Same, same, but different. Journal of Tourism and Cultural Change. doi: 10.1080/14766825.2016.1253704

Porananond, P. (2015). Khun Tok dinner: The transformation of a Lanna eating style into a tourist attraction in Chiang Mai, Thailand. International Journal of Asia Pacific Studies, 11(1), 129-144.

Prachachat. (2016, August 5). 'ท่องเที่ยวเชิงอาหาร คาดปี' 59 โต 5 แสนล้าน (Culinary tourism estimated to grow by 500 billion Baht in 2016). Matichon Public Co., Ltd. Retrieved from http://www.prachachat.net/news_detail. php?newsid $=1470287507$

Punch, K. F. (1998). Introduction to social research: Quantitative and qualitative approaches (1st ed.). London, UK: SAGE Publications.

Quan, S., \& Wang, N. (2004). Towards a structural model of the tourist experience: An Illustration from food experience in tourism. Tourism Management, 25(3), 297-305.

Reynolds, C. J. (2002). Thai identity in the age of globalisation. In C. J. Reynolds (Ed.), National identity and its defenders: Thailand Today (p. 31). Chiang Mai, Thailand: Silworm Books.

Sakdiyakorn, M., \& Sivarak, O. (2015). Innovation management in cultural heritage tourism: Experience from the Amphawa waterfront community, Thailand. Asia Pacific Journal of Tourism Research, 21(2), 221-238.

Salamone, F. A. (1997). Authenticity in tourism: The San Angel Inn. Annals of Tourism Research, 24(2), 305-321.

Seo, S., Yun, N., \& Kim, O. Y. (2017). Destination food image and intention to eat destination foods: A view from Korea. Current Issues in Tourism, 20(2), 135-156.

Shepherd, R. (2002). Commodification, culture and tourism. Tourist Studies, 2(2), 183-201.

Sims, R. (2009). Food, place and authenticity: Local food and the sustainable tourism experience. Journal of Sustainable Tourism, 17(3), 321-336.

Siri-umpai, W. (2012). ปัจจัยที่มีอิทธิพลต่อพฤติกรรมการซื้อสินค้ าของนักท่องเที่ยวตลาดโบราณบ้านสะแกกรัง (ถนนคนเดินตรอก โรงยา) จังหวัดอุทัยธานี. Uthai Thani Province. Retrieved from http://www.research.rmutt.ac.th/?p=8658

Smith, S., \& Xiao, H. (2008). Culinary tourism supply chains: A preliminary examination. Journal of Travel Research, 46(3), 289-299.

Steiner, C. J., \& Reisinger, Y. (2006). Understanding existential authenticity. Annals of Tourism Research, 33(2), 299-318.

Stoilova, E. (2015). The Bulgarinaization of yoghurt: Connecting home, taste, and authenticity. Food and Foodways: Explorations in the History and Culture of Human Nourishment, 23(1-2), 14-35. 
Suntikul, W. (2013). Nostalgia-motivated Thai domestic tourism at Amphawa. In International Critical Tourism Studies Conference V, Sarajevo, Bosnia and Herzegovina.

Sutton, D. E. (1998). Memories cast in stone: The relevance of the past in everyday life. Oxford, UK: Berg.

Tamsingh, T. (2017). บทความ: การท่องเที่ยวเชิงอาหาร (gastronomy tourism). National News Bureau of Thailand. Retrieved from http://thainews.prd.go.th/website_th/news/ news detail/TNRPT6003210010005

Tourism Authority of Thailand. (2009). คู่มือนำเที่ยว 15 ตลาดบก 16 ตลาดน้า (Guidebook to 15 ground markets and 16 floating markets). Bangkok, Thailand: Author.

Taylor, J. P. (2001). Authenticity and sincerity in tourism. Annals of Tourism Research, 28(1), 7-26.

Thailandometers. (2016). Thailandometers: Statistics of Thailand updated by real time. Retrieved from http://www. thailandometers.mahidol.ac.th/index.php?\#population

Thansettakij. (2016, January 8). ท่องเที่ยวไทยปี 58 ทำสถิติใหม่ โกยรายได้ทะลุเป้า 2.23 ล้านล้าน (New records for Thai tourism: Tourist receipt reaching at $2.23 \mathrm{~m}$ million Baht). Retrieved from http://www.thansettakij.com/2016/01/08/ 25115

Thomas, J., \& Harden, A. (2008). Methods for the thematic synthesis of qualitative research in systematic reviews. Medical Research Methodology, 8(45),1-10.

Tiberghien, G., Bremner, H., \& Milne, S. (2017). Performance and visitors' perception of authenticity in ecocultural tourism. Tourism Geographies, 19(2), 287-300.

Tucker, H., \& Lynch, P. (2005). Host-guest dating: The potential of improving the customer experience through host-guest psychology. Journal of Quality Assurance in Hospitality \& Tourism, 5(2-4), 11-32.

Tunbridge, J. E., \& Ashworth, G. J. (1996). Dissonant heritage: The management of the past as a resource in conflict. Chichester, UK: John Wiley \& Sons.

Van Esterik, P. (1992). From marco polo to Mcdonald's: Thai cuisine in transitio. Food and Foodways: Explorations in the History and Culture of Human Nourishment, 5(2), 177-193.

Walter, P. G. (2015). Travelers' experiences of authenticity in "hill tribe" tourism in Northern Thailand. Tourist Studies, 16(2), 1-18.

Walter, P. G. (2016). Culinary tourism as living history: Staging, tourist performance and perceptions of authenticity in Thai cooking school. Journal of Heritage Tourism, 12(4), 365-379.

Wang, N. (1999). Rethinking authenticity in tourism experience. Annals of Tourism Research, 26(2), 349-370.

Wang, Y. (2007). Customized authenticity begins at home. Annals of Tourism Research, 34(3), 789-804.

Wattanacharoensil, W., \& Sakdiyakorn, M. (2015). The potential of floating markets for creative tourism: A study in Nakhon Pathom Province, Thailand. Asia Pacific Journal of Tourism Research, 21(1), 1-27.

Wattanacharoensil, W. \& Schuckert, M. (2014). Reviewing Thailand's master plans and policies: Implications for creative tourism? Current Issues in Tourism, 19(10), 1045-1070.

World Tourism Organization. (2015). UNWTO tourism highlights 2015. Retrieved from http://www.e-unwto.org/doi/ pdf/10.18111/9789284416899

Wilk, R. R. (1999). Real Belizean food: Building local identity in the transnational Caribbean. American Anthropologist, 101(2), 244-255.

Xie, P. F. (2011). Authenticating ethnic tourism. Bristol, UK: Channel View Publications.

Yasmeen, G. (2000). Not "from scratch": Thai food systems and "public eating." Journal of Intercultural Studies, 21(3), 341-352.

Yeoman, I., Brass, D., \& McMahon-Beattie, U. (2006). Current issues in tourism: The authentic tourist. Tourism Management, 28, 1128-1138.

Yeoman, I., McMahon-Beattie, U., Fields, K., Albrecht, J. N., \& Meethan, K. (2015). An introduction to the future. In I. Yeoman, U. McMahon-Beattie, K. Fields, J. N. Albrecht, \& K. Meethan (Eds.), The future of food tourism: Foodies, experiences, exclusivity, visions and political capital (pp. 3-10). Bristol, UK: Channel View Publications.

Yodsurang, P., Hiromi, M., \& Yasufumi, U. (2016). A traditional community in the Chao Phraya River Basin: Classification and characteristics of a waterfront community complex. Asian Culture and History, 8(1), 57-68.

Zhou, Q. B., Zhang, J., Zhang, H., \& Ma, J. (2015). A structural model of host authenticity. Annals of Tourism Research, 55, 28-45.

Zhu, Y. (2012). Performing heritage: Rethinking authenticity in tourism. Annals of Tourism Research, 39(3), 1495-1513. 